СИНТЕЗ ТА АНАЛІЗ БІОЛОГІЧНО АКТИВНИХ РЕЧОВИН

Recommended by Doctor of Pharmacy, Professor S. V. Kolisnyk

UDC 615.011:615.2:543.544.5.0687:54.062

https://doi.org/10.24959/nphj.17.2180

V. Yu. Anisimov' ${ }^{1}$, V. O. Gelmboldt ${ }^{1}$, S. M. Gubar², A. V. Myhal' ${ }^{2}$ N. Yu. Bevz²,

V. A. Georgiyants ${ }^{2}$

${ }^{1}$ Odessa National Medical University

${ }^{2}$ National University of Pharmacy

\title{
The use of the HPLC method for the quantitative determination of cetylpyridinium hexafluorosilicate in a dental gel
}

\begin{abstract}
Cetylpyridinium hexafluorosilicate has been proposed as a caries preventive and antibacterial agent for use as a gel for oral application, which requires development of quality control methods.

Aim. To develop the method for the quantitative determination of cetylpyridinium hexafluorosilicate in a dosage form using HPLC.

Materials and methods. The object of the study is the experimental dosage form - a gel proposed for use in dental practice. The research method is HPLC.

Results and discussion. The method for the quantitative determination of the active component, which allows determining cetylpyridinium hexafluorosilicate in the gel in the presence of excipients of the dosage form, has been developed. It is recommended to carry out this determination by the HPLC method using the column of $150 \times 4.6 \mathrm{~mm}$ in size filled with octadecyl silica gel for chromatography, the sorbent particle size of $3.5 \mu \mathrm{m}$, a mixture of perchlorate buffer solution $(\mathrm{pH} 3.0)$ and acetonitrile $(30: 70)$ as a mobile phase and UV detection at the wavelength of $254 \mathrm{~nm}$.

Conclusions. The conditions of the chromatographic study by the HPLC method proposed provide sufficient selectivity for the quantitative determination of cetylpyridinium hexafluorosilicate in the dosage form, and it has been confirmed by studying the validation characteristics of the method.
\end{abstract}

Key words: cetylpyridinium hexafluorosilicate; gel; assay; HPLC method; validation

В. Ю. Анісімов, В. О. Гельмбольдт, С. М. Губар, А. В. Мигаль, Н. Ю. Бевз, В. А. Георгіянц

Використання методу ВЕРХ для кількісного визначення цетилпіридинію гексафлуоросилікату у стоматологічному гелі

Цетилпіридинію гексафлуоросилікат запропонований як карієс-профілактичний та антибактеріальний засіб для застосування у вигляді гелю з метою оральних аплікацій, який потребує розробки методик контролю якості.

Мета роботи. Розробка методики кількісного визначення цетилпіридинію гексафлуоросилікату методом ВEPX у лікарській формі.

Матеріали та методи. Об'єктом дослідження є експериментальна лікарська форма гель, запропонована для використання у стоматологічній практиці. Метод дослідження - BEPX.

Результати та їх обговорення. У ході дослідження розроблена методика кількісного визначення діючого компоненту, яка дозволяє визначити цетилпіридинію гексафлуоросилікат у гелі у присутності допоміжних речовин лікарської форми. Визначення рекомендовано проводити методом ВЕРХ на колонці розміром $150 \times 4,6$ мм, заповненій силікагелем октадецилсилільним для хроматографії з розміром зерен сорбенту 3,5 мкм з використанням як рухомої фази суміші перхлоратного буферного розчину рН 3,0 і ацетонітрилу (30 : 70) та УФ-детектуванням за довжини хвилі 254 нм.

Висновки. Запропоновані умови хроматографічного дослідження методом BEPX забезпечують достатню селективність кількісного визначення цетилпіридинію гексафрлуоросилікату у лікарській фрормі, що підтверджено вивченням валідаційних характеристик методики.

Ключові слова: цетилпіридинію гексафрлуоросилікат; гель; кількісне визначення; метод ВЕРХ; валідація

В. Ю. Анисимов, В. О. Гельмбольдт, С. Н. Губарь, А. В. Мигаль, Н. Ю. Бевз, В. А. Георгиянц

\section{Использование метода ВЭЖХ для количественного определения цетилпиридиния гексафторосиликата в стоматологическом геле}

Цетилпиридиния гексафторосиликат предложен в качестве кариес-профилактического и антибактериального средства для применения в виде геля для оральных аппликаций, для которого необходима разработка методик контроля качества.

Цель работы. Разработка методики количественного определения цетилпиридиния гексафторосиликата методом ВЭЖХ в лекарственной форме. 
Материалы и методы. Объектом исследования является экспериментальная лекарственная форма гель, предлагаемая для использования в стоматологической практике. Метод исследования - ВЭЖХ.

Результаты и их обсуждение. В ходе исследования разработана методика количественного определения действующего компонента, позволяющая определять цетилпиридиния гексафторосиликат в геле в присутствии вспомогательных веществ лекарственной фрормы. Определение рекомендовано проводить методом ВЭЖХ на колонке размером 150 ×4,6 мм, заполненной силикагелем октадецилсилильным для хроматографии с размером зерен сорбента 3,5 мкм с использованием в качестве подвижной фразы смеси перхлоратного буферного раствора рН 3,0 и ацетонитрила (30 : 70), УФ-детектирование при длине волны 254 нм.

Выводы. Предложенные условия хроматографического исследования методом ВЭЖХ обеспечивают достаточную селективность количественного определения цетилпиридиния гексафторосиликата в лекарственной форме, что подтверждено изучением валидационных характеристик методики.

Ключевые слова: цетилпиридиния гексафрторосиликат; гель; количественное определение; метод ВЭЖХ; валидация

It is known that the element of fluorine is involved in the mineral metabolism in the bone tissue and teeth due to the caries-protective and osteoprotective activity. Unfortunately, overdose with fluorine can lead to binding of calcium ions to inert calcium fluoride and appearance of the hepatotoxic activity. It has been found that among various complex fluoride forms only hexafluorosilicates reduce the ability of fluorine to bind calcium ions and practically do not possess the hepatotoxic activity compared to sodium fluoride.

The biochemical studies have proven that the mechanism of caries preventive action of fluorine preparations is based on their ability to increase the mineralizing index and the level of non-specific immunity of the teeth pulp. Cetylpyridinium hexafluorosilicate synthesized at the premises of the Odessa National Medical University showed the highest activity in the dose of $15 \mathrm{mg} / \mathrm{kg}$ when used as a gel for oral application [1].

The composition and technology of the gel for oral application has been developed and experimentally proven. Its composition includes a gel former - hydroxyethyl cellulose, solubilizer - PEG-40, sorbitol introduced to provide moderate osmotic properties, and sodium benzoate proposed as a preservative [2].

The aim of the work is to use the high-performance liquid chromatography method for the quantitative determination of cetylpyridinium hexafluorosilicate in the gel composition.

\section{Materials and methods}

Cetylpyridinium hexafluorosilicate RS with the nominal content of $100.17 \%$; hydroxyethyl cellulose, PEG-40 (b. 40 manufactured by the JSC TOS plant "BARVA"), sorbitol (b. KV9523 manufactured by Cerestar), sodium benzoate, mint oil (b. L01-211D50, Pharmaceuticals and cosmetics, 07.11.2011), the class A glassware for measuring, reagents meeting the requirements of the State Pharmacopeia of Ukraine (SPhU), as well as an AB-204/A Mettler Toledo analytical balance were used in the study.

The chromatographic determination was carried out on a ProStar (Varian, USA) chromatograph under the following conditions:

Test solution. Place approximately $2.5 \mathrm{~g}$ (accurate weight) of the gel in a $50 \mathrm{ml}$ volumetric flask, add $30 \mathrm{ml}$ of water $R$, sonicate for $15 \mathrm{~min}$. Stir the solution using a laboratory mixer till the complete dissolution of the gel. Dilute the solution to the volume with the same solvent, mix thoroughly, and filter through a "red tape" paper filter. Filter the solution obtained through a $0.45 \mu \mathrm{m}$ membrane filter.

Standard solution. Place approximately $50 \mathrm{mg}$ (accurate weight) cetylpyridinium hexafluorosilicate $R S$ in a $50 \mathrm{ml}$ volumetric flask, dissolve in water $R$, dilute the solution to the volume with the same solvent and mix. Filter the solution obtained through a $0.45 \mu \mathrm{m}$ membrane filter.

Column: Waters XBridge ${ }^{\mathrm{TM}} \mathrm{C} 18,0.15 \mathrm{~m} \times 4.5 \mathrm{~mm}$ with the precolumn filled with octadecyl silica gel for chromatography with the sorbent particle size of $3.5 \mu \mathrm{m}$.

Column temperature: $25^{\circ} \mathrm{C}$.

Mobile phase: perchlorate buffer solution with $\mathrm{pH}$ 3.0 - acetonitrile $R(30: 70)$.

The flow rate of the mobile phase: $1.5 \mathrm{ml} / \mathrm{min}$.

Detection: spectrophotometry at the wavelength of $254 \mathrm{~nm}$.

The volume of injection: $20 \mu \mathrm{L}$.

The run time: $20 \mathrm{~min}$.

The standard solution and the test solution were chromatographed alternately.

The quantitative content of cetylpyridinium hexafluorosilicate in $100 \mathrm{~g}$ of the drug $(\mathrm{g})$ was calculated by the formula:

$$
X=\frac{S_{1} \cdot m_{0} \cdot P \cdot 50 \cdot 1 \cdot 100}{S_{0} \cdot m_{1} \cdot 50 \cdot 10 \cdot 100},
$$

where: $S_{1}$ - is the average value of the peak area of cetylpyridinium hexafluorosilicate calculated from the chromatograms of the test solution; $S_{0}$ - is the average value of the peak area of cetylpyridinium hexafluorosilicate calculated from the chromatograms of the standard solution; $m_{1}-$ is the sample weight of the drug, $(\mathrm{g}) ; m_{0}-$ is the sample weight of cetylpyridinium hexafluorosilicate $R S,(\mathrm{~g}) ; P$ - is the amount of active substance in cetylpyridinium hexafluorosilicate RS, (\%).

\section{The system suitability}

The standard solution is used to verify the suitability of the chromatographic system. The chromatographic system is considered to be suitable if the following requirements of the system suitability test are met:

- the efficiency of the chromatographic column calculated for the main peak is not less than 5000 theoretical plates; 
Table 1

The relative standard deviation (RSD) calculated for the areas of the main peaks of the repeated chromatograms

\begin{tabular}{|c|c|c|c|c|c|c|c|}
\hline $\begin{array}{c}\text { The number of } \\
\text { parallel injections }\end{array}$ & 2 & 3 & 4 & 5 & 6 & 7 & 8 \\
\hline RSD, \% & 0.51 & 1.34 & 1.92 & 2.37 & 2.75 & 3.08 & 3.38 \\
\hline
\end{tabular}

- the symmetry coefficient calculated for the main peak is not less than 2.0;

- the relative standard deviation (RSD) calculated for the areas of the main peaks of the repeated chromatograms must not exceed the values given in Tab. 1: In order to meet the requirements of the chromatographic system suitability the changes in the chromatographic conditions within the limits are permitted by the SPhU, 2.2.46, "Methods of chromatographic separation".

Preparation of the buffer solution with $\mathbf{p H}$ 3.0. Dissolve $2.0 \mathrm{~g}$ of sodium perchlorate $R$ in $300 \mathrm{ml}$ of water $R$, add $0.5 \mathrm{ml}$ of triethylamine $R$ and mix. Dilute the $\mathrm{pH}$ of the solution obtained to $3.0 \pm 0.1$ with diluted phosphoric acid $R$. Filter the resulting solution through a $0.45 \mu \mathrm{m}$ membrane filter.

\section{Results and discussion}

The physicochemical properties of cetylpyridinium hexafluorosilicate described in the literature were used when developing the method for the quantitative determination of the active pharmaceutical ingredient in the composition of the gel [3].

The existing redox method of assay for cetylpyridinium hexafluorosilicate in the substance [4] in this case did not give a positive result because of the presence of excipients in the dosage form. To develop a method for the quantitative determination of the gel active component according to the requirements of the SPhU [5] it was necessary to choose the conditions under which enable the complete separation of the active substance and excipients was possible within a reasonable time. Various combinations of the mobile phase and the $\mathrm{pH}$ values of the medium were tested when developing this method.

Based on the experimental data it was found that as the mobile phase it was expedient to use the mixture of perchlorate buffer solution with $\mathrm{pH} 3.0$ and acetonitrile in the ratio of $30: 70$. Separation of the active component and excipients that were not met under these conditions was achieved with isocratic elution. Water for chromatography was chosen as a solvent for preparation of the model, test and reference solutions.

The gel composition contains hydroxyethyl cellulose and sorbitol, which complicated the sample preparation and required additional filtering through a paper filter.

The conditions of the chromatographic determination proposed using the method of high performance liquid chromatography (HPLC) provide sufficient selectivity. The solution of the standard sample of cetylpyridinium hexafluorosilicate, the test solution of the drug

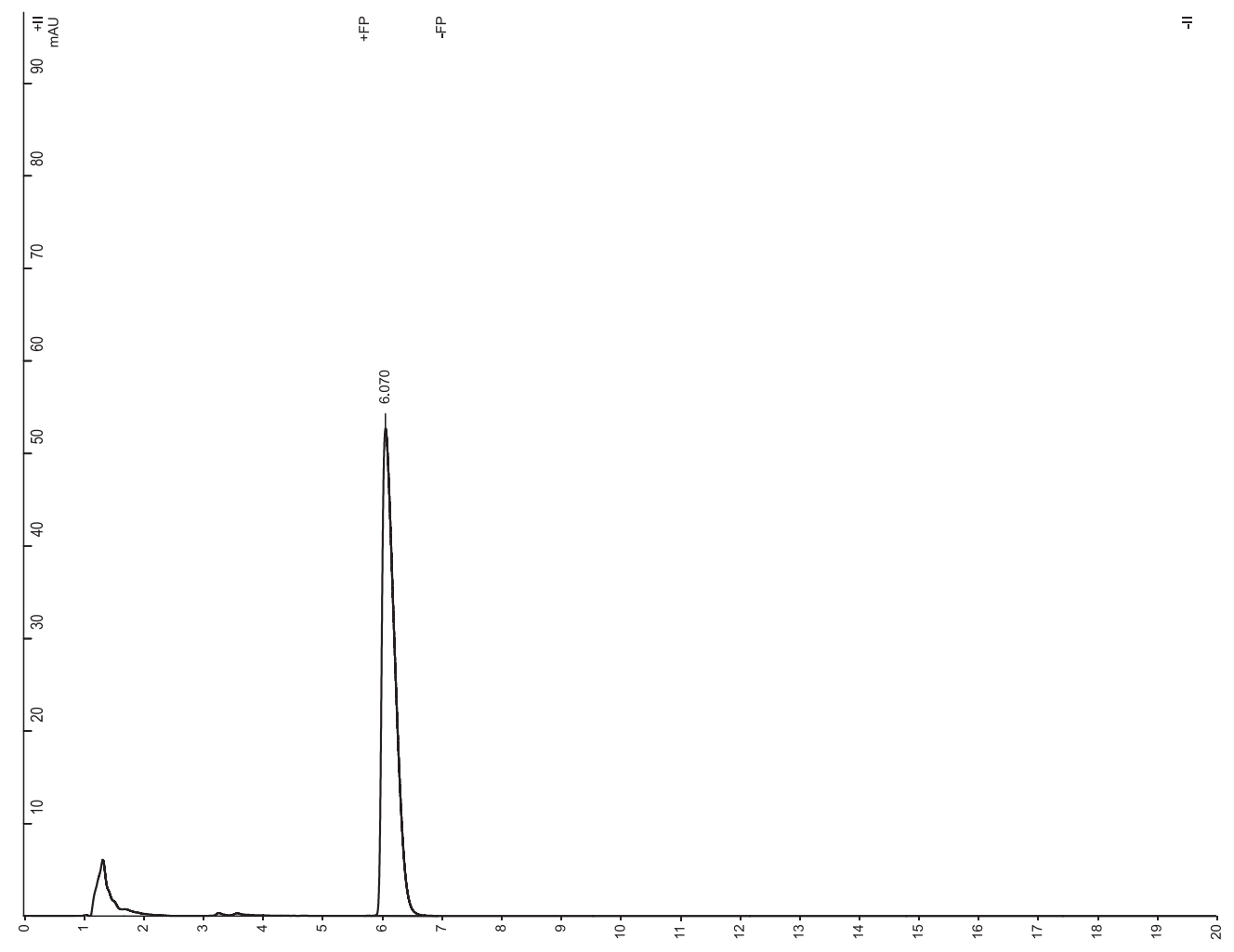

Fig. 1. The chromatogram of the standard solution of cetylpyridinium hexafluorosilicate 


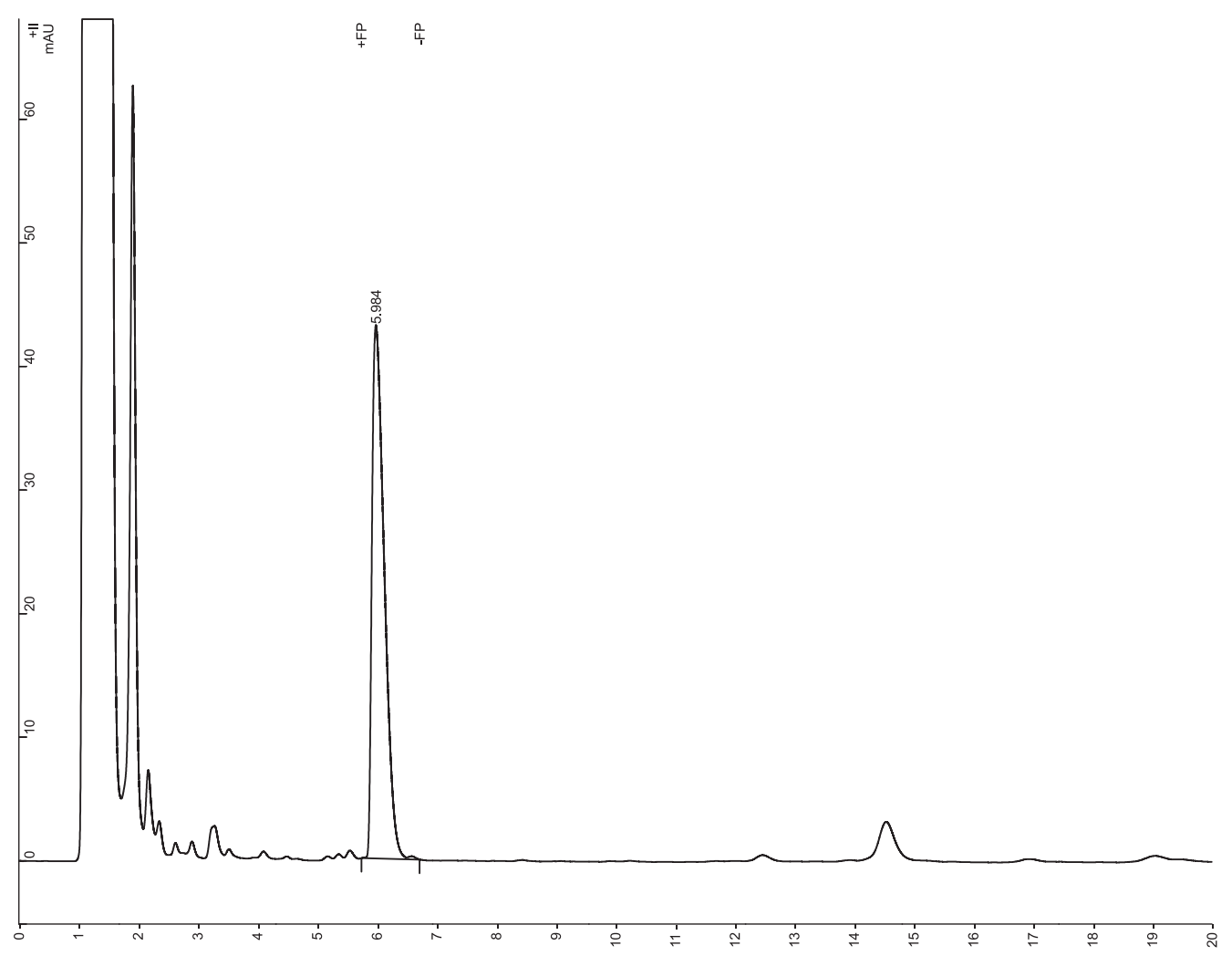

Fig. 2. The chromatogram of the test solution

and the placebo solution were prepared and analyzed to verify selectivity of the method. The chromatograms obtained in the study of solutions are shown in Fig. 1-3.

As can be seen in the chromatogram of the placebo solution (Fig. 3), there are no peaks that can interfere with the determination of cetylpyridinium hexafluorosilicate, and it may indicate the reproducibility of the method.

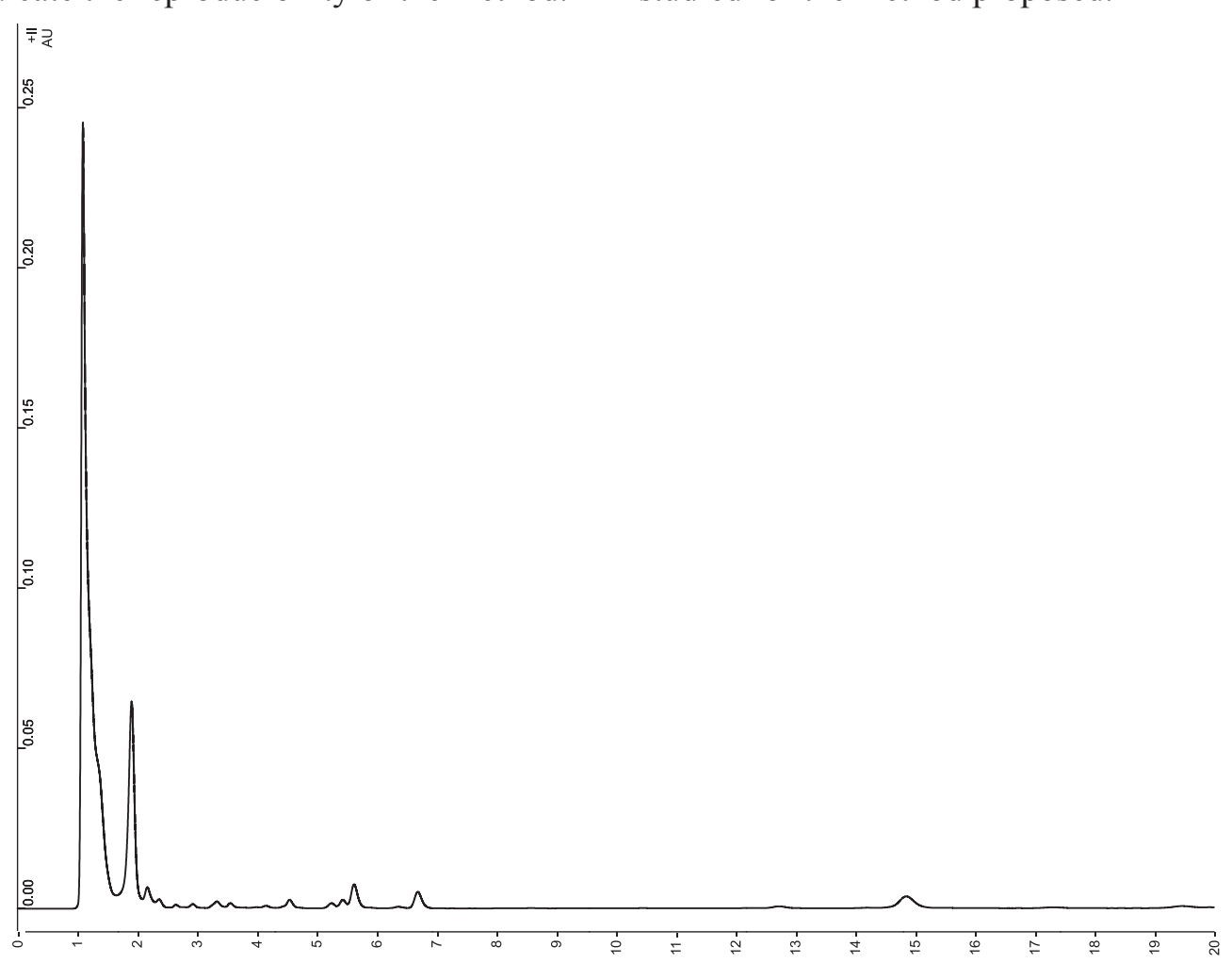

Fig. 3. The chromatogram of the placebo solution
The studies have shown that the retention time of the cetylpyridinium hexafluorosilicate peak in the test solution coincides with the retention time of the main peak in the reference solution with an accuracy of $\pm 2 \%$. A number of validation characteristics such as specificity, linearity, convergence, precision and accuracy were studied for the method proposed. 
To estimate the error of the sample preparation of the test solution and standard solution the theoretical values for analytic operation uncertainty were calculated, it was $\Delta \mathrm{sp}=0.89 \% \leq \mathrm{B} \cdot 0.32=1.6 \%$. Therefore, the estimated uncertainty of the sample preparation of the method of analysis in general should provide sufficient accuracy of measurements.

To prove the specificity of the method it is sufficient to meet all requirements regarding the criteria of linearity, correctness and precision since for the quantitative determination of cetylpyridinium hexafluorosilicate in the gel the HPLC method, which is specific, is used.

The assessment of linearity was performed in the entire range of the method application using the standard method. The study of the character of dependence of the peak area on the concentration was carried out using 9 model solutions with accurate weight of concentra-

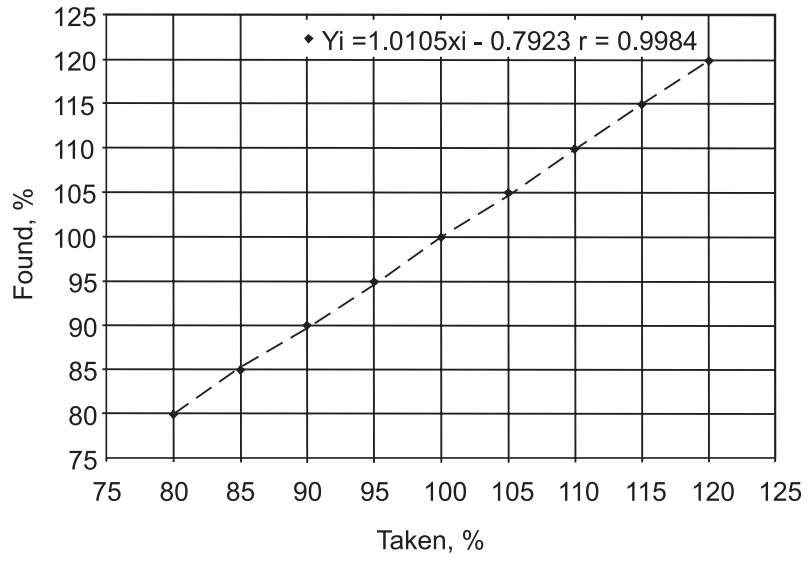

Fig. 4. The linear dependence of the peak area on the concentration of cetylpyridinium in the normalized coordinates

Table 2

Metrological characteristics of the linear dependence

\begin{tabular}{|c|c|c|c|}
\hline Parameter & Value & $\begin{array}{c}\text { Criterion (for tolerances } \\
\text { from } 95 \% \text { to } 105 \%, \mathrm{~g}=9 \text { ) }\end{array}$ & Conclusion \\
\hline $\mathrm{b}$ & 0.9972 & - & \\
\hline $\mathrm{S}_{\mathrm{b}}$ & 0.0065 & - & \\
\hline $\mathrm{a}$ & 0.1708 & $\begin{array}{c}1) \leq 1.895 \mathrm{~S}_{\mathrm{a}}=1.24, \\
\text { 2) if not executed } 1 \text { ), then } \leq 2.6\end{array}$ & corresponds \\
\hline $\mathrm{S}_{\mathrm{a}}$ & 0.6545 & - & corresponds \\
\hline $\mathrm{S}_{0}$ & 0.2514 & $<0.84$ & corresponds \\
\hline $\mathrm{r}$ & 0.9984 & $\geq 0.9981$ & \\
\hline
\end{tabular}

Table 3

The results of analysis of the model solutions and their statistical processing

\begin{tabular}{|c|c|c|c|c|}
\hline $\begin{array}{l}\text { The model } \\
\text { solution No. }\end{array}$ & $\begin{array}{c}\text { Introduced to the nominal } \\
\text { amount }(\mathrm{Xi}, \%)\end{array}$ & $\begin{array}{c}\text { The peak } \\
\text { area }\end{array}$ & $\begin{array}{l}\text { Found to the nominal } \\
\text { amount }(Y i, \%)\end{array}$ & $\begin{array}{l}\text { Found in \% to the introduced } \\
\qquad \mathrm{Zi}=100(\mathrm{Yi} / \mathrm{Xi})\end{array}$ \\
\hline 1 & 80.00 & 690186 & 79.70 & 99.63 \\
\hline 2 & 85.00 & 737238 & 85.14 & 100.16 \\
\hline 3 & 90.00 & 778533 & 89.91 & 99.90 \\
\hline 4 & 95.00 & 822506 & 94.98 & 99.98 \\
\hline 5 & 100.00 & 866068 & 100.01 & 100.01 \\
\hline 6 & 105.00 & 909201 & 105.00 & 100.00 \\
\hline 7 & 110.00 & 947054 & 109.37 & 99.42 \\
\hline 8 & 115.00 & 996612 & 115.09 & 100.08 \\
\hline 9 & 120.00 & 1037341 & 119.79 & 99.83 \\
\hline \multicolumn{4}{|c|}{ Mean, Z, \% } & 99.89 \\
\hline \multicolumn{4}{|c|}{ Relative standard deviation, $\mathrm{RSD}_{z^{\prime}} \%$} & 0.23 \\
\hline \multicolumn{4}{|c|}{ Relative confidence interval, $\Delta_{\mathrm{Z}}(\%)=\mathrm{t}(95 \%, \mathrm{n}-1) \times \mathrm{RSD}_{\mathrm{Z}}=1.860 \times \mathrm{RSD}_{\mathrm{Z}} \%$} & 0.43 \\
\hline \multicolumn{4}{|c|}{ Critical values for convergence of results, $\Delta \mathrm{as}, \%$} & 3.20 \\
\hline \multicolumn{4}{|c|}{ Systematic error $\delta=|Z-100|$} & 0.11 \\
\hline \multicolumn{4}{|c|}{$\begin{array}{l}\text { Criterion of the systematic error insignificance } \\
\begin{array}{l}\text { 1) statistical uncertainty: } \delta \% \leq 1.03 / 3=0.34(0.14<0.348) \text { if it is not satisfied } 1) \text {, then } \\
\text { 2) practical uncertainty: } \delta \% \leq 0.32 \times 1.6=0.51 \%(0.14<0.51)\end{array}\end{array}$} & satisfied \\
\hline \multicolumn{4}{|c|}{ The overall conclusion of the method } & correct \\
\hline
\end{tabular}


Table 4

Metrological characteristics of the average results

\begin{tabular}{|c|c|c|c|c|c|c|c|c|c|}
\hline $\mathrm{m}$ & $\mathrm{n}$ & $x_{i}$ & $\mathrm{x}_{\mathrm{av}}$ & $\mathrm{S}^{2}$ & $\mathrm{~S}_{\mathrm{av}}$ & $\mathrm{P}$ & $t(P, v)$ & $\begin{array}{c}\text { Confidence } \\
\text { interval }\end{array}$ & $\varepsilon, \%$ \\
\hline \multirow{6}{*}{6} & \multirow{6}{*}{5} & 0.1618 & \multirow{6}{*}{0.1611} & \multirow{6}{*}{$1.55 \times 10^{-6}$} & \multirow{6}{*}{$5.08 \times 10^{-4}$} & \multirow{6}{*}{95} & \multirow{6}{*}{0.2756} & \multirow{6}{*}{$\begin{array}{c}0.1611 \pm \\
0.0005\end{array}$} & \multirow{6}{*}{0.81} \\
\hline & & 0.1606 & & & & & & & \\
\hline & & 0.1599 & & & & & & & \\
\hline & & 0.1606 & & & & & & & \\
\hline & & 0.1601 & & & & & & & \\
\hline & & 0.1632 & & & & & & & \\
\hline
\end{tabular}

tions $(80,85,90,95,100,105,110,115$, and $120 \%)$ for analysis.

For each of these nine solutions of the sample the average values of the peak areas $(\mathrm{Si})$ were calculated. Plotting of the calibration curve was carried out in the normalized coordinates (Fig. 4) after processing of the results obtained using the least squares method [5].

The statistical values b, Sb, a, Sa, $\mathrm{Sr}$ (residual standard deviation) and $\mathrm{r}$ (correlation coefficient) calculated are shown in Fig. 4 and Tab. 2. Requirements for linear dependence parameters are performed in the entire range of application of the method proposed (80-120\%).

To measure and calculate the metrological evaluation of convergence and correctness of the method three values of the peak areas for the standard solution and 27 values of the peak areas for model solutions were obtained. The actual values $\left(X_{i}\right)$, the ratio of the average values of the peak areas for each of 27 solutions to the average value of the peak area of the standard solution were calculated, the values $X i=\left(C_{i} / C_{s}\right) \cdot 100 \%, Y_{i}=\left(S_{i} / S_{s}\right) \cdot 100 \%$, as well as the value $Z_{i}=\left(Y_{i}\left(X_{i}\right) \cdot 100 \%\right.$ were obtained (Tab. 3 ).
The results of determination of the quantitative content of cetylpyridinium hexafluorosilicate in the dental gel studied are given in Tab. 4.

The analysis of the data has shown that the content of the active ingredient in the gel is $0.1611 \mathrm{~g} / 100 \mathrm{~g}$ (normally $0.1660 \mathrm{~g} / 100 \mathrm{~g}$ ), the relative uncertainty of the result of the individual determination is $0.81 \%$.

\section{CONCLUSIONS}

1. The method of the quantitative determination of cetylpyridinium hexafluorosilicate developed using the HPLC method is suitable for the quality control of the active substance in the dental gel. It has been proven that the content of the active component of the dental gel is within the permissible limits, and the metrological characteristics of the method allow recommending it for standardization of the product.

2 . The validation characteristics of the method do not exceed the critical value of the error $(1.6 \%)$ and are characterized by qualitative analytical indicators.

Conflict of Interests: authors have no conflict of interests to declare.

\section{REFERENCES}

1. Lepsky, V. V. Biochemical mechanisms of the caries prophylaxis action of hexafluorosilicates / V. V. Lepsky, V. Yu. Anisimov, V. V. Lepsky // J. of Education, Health and Sport. - 2015. - Vol. 5, Issue 11. - P. 289-299.

2. Анісімов, В. Ю. Розробка складу та технології карієспрофілактичного гелю / В. Ю. Анісімов, В. О. Гельмбольдт, Н. П. Половко // Вісник фармації. - 2015. - № 4 (84). - C. 58-61.

3. Development of methods for identification of cetylpyridinium hexafluorosilicate / V. O.Gelmboldt, V. Yu. Anisimov, N. Yu. Bevz, V. A. Georgiyants // Der Pharma Chemica. - 2016. - Vol. 8, Issue 1. - P. 169-173.

4. Development of the quantitative determination method for a new caries-preventive compound / V. Yu. Anisimov, V. O. Gelmboldt, N. Yu. Bevz, V. A. Georgiyants // Вісник фармації. - 2016. - № 1 (85). - C. 15-18.

5. Державна фармакопея України : в 3-х т. / Державне підприємство «Український науковий фармакопейний центр якості лікарських засобів». - 2-е вид. - Х. : Український науковий фармакопейний центр якості лікарських засобів, 2015. - Т. 1. - 1128 с.

\section{REFERENCES}

1. Lepsky, V. V., Anisimov, V. Yu., Lepsky, V. V. (2015). Biochemical mechanisms of the caries prophylaxis action of hexafluorosilicates. Journal of Education, Health and Sport, 5 (11), 289-299.

2. Anisimov, V. Yu., Helmboldt, V. O., Polovko, N. P. (2015). Visnik farmaciï, 4 (84), 58-61.

3. Gelmboldt, V. O., Anisimov, V. Yu., Bevz, N. Yu., Georgiyants, V. A. (2016). Development of methods for identification of cetylpyridinium hexafluorosilicate. Der Pharma Chemica, 8 (1), 169-173.

4. Anisimov, V. Yu., Gelmboldt, V. O., Bevz, N. Yu., Georgiyants, V. A. (2016). Development of the quantitative determination method for a new caries-preventive compound. Visnik farmaciï, 1 (85), 15-18.

5. Derzhavna Farmakopeia Ukrainy, v 3 tomakh, 2-e vyd. (2015). Kharkiv: Ukrainskyi naukovyi farmakopeinyi tsentr yakosti likarskykh zasobiv, 1128. 


\section{Information about authors:}

Anisimov V. Yu., Candidate of Biology (Ph.D.), associate professor of the Pharmaceutical Chemistry Department, dean of the Pharmaceutical Faculty, Odessa National Medical University. E-mail: vladimiranisimov@ukr.net

Gelmboldt V. O., Doctor of Chemistry (Dr. habil.), professor, the head of the Pharmaceutical Chemistry Department, Odessa National Medical University. E-mail: vgelmbold@te.net.ua

Gubar S. M., Candidate of Pharmacy (Ph.D.), head of the State Research Laboratory on Drug Quality Control, National University of Pharmacy. E-mail: gubarsn@ukr.net Myhal A. V., postgraduate student of the Pharmaceutical Chemistry Department, National University of Pharmacy. E-mail: artem.migal@gmail.com Bevz N. Yu., Candidate of Pharmacy (Ph.D.), associate professor of the Pharmaceutical Chemistry Department, National University of Pharmacy. E-mail: nata.bevz.60@gmail.com

Georgiyants V. A., Doctor of Pharmacy (Dr. habil.), professor, head of the Pharmaceutical Chemistry Department, National University of Pharmacy. E-mail: vgeor@ukr.net

\section{Відомості про авторів:}

Анісімов В. Ю., канд. біол. наук, доцент кафедри фармацевтичної хімії, декан фармацевтичного факультету, Одеський національний медичний університет. E-mail: vladimiranisimov@ukr.net

Гельмбольдт В. О., д-р хім. наук, професор, завідувач кафедри фармацевтичної хімії, Одеський національний медичний університет. E-mail: vgelmbold@te.net.ua Губар С. М., канд. фарм. наук, завідувач Державної науково-дослідної лабораторії з контролю якості лікарських засобів, Національний фармацевтичний університет. E-mail: gubarsn@ukr.net

Мигаль А. В., аспірант кафедри фармацевтичної хімії, Національний фармацевтичний університет. E-mail: artem.migal@gmail.com

Бевз Н. Ю., канд. фарм. наук, доцент кафедри фармацевтичної хімії, Національний фармацевтичний університет. E-mail: nata.bevz.60@gmail.com

Георгіянц В. А., д-р фарм. наук, професор, завідувач кафедри фармацевтичної хімії, Національний фармацевтичний університет. Е-таil: vgeor@ukr.net Сведения об авторах:

Анисимов В. Ю., канд. биол. наук, доцент кафедры фармацевтической химии, декан фармацевтического факультета, Одесский национальный медицинский университет. E-mail: vladimiranisimov@ukr.net

Гельмбольдт В. О., д-р хим. наук, профессор, заведующий кафедрой фармацевтической химии, Одесский национальный медицинский университет. E-mail: vgelmbold@te.net.ua.

Губарь С. Н., канд. фарм. наук, заведующая Государственной научно-исследовательской лабораторией по контролю качества лекарственных средств, Национальный фармацевтический университет. E-mail: gubarsn@ukr.net

Мигаль А. В., аспирант кафедры фармацевтической химии, Национальный фармацевтический университет. E-mail: artem.migal@gmail.com

Бевз Н. Ю., канд. фарм. наук, доцент кафедры фармацевтической химии, Национальный фармацевтический университет. E-mail: nata.bevz.60@gmail.com Георгиянц В. А., д-р фарм. наук, профессор, заведующая кафедрой фармацевтической химии, Национальный фармацевтический университет. E-mail: vgeor@ukr.net 